\title{
GIS-BASED VIEWSHED ANALYSIS ON THE CONSERVATION PLANNING OF HISTORIC TOWNS: THE CASE STUDY OF XINCHANG, SHANGHAI
}

\author{
Longyun Ren ${ }^{1}$, Yongkang Cao ${ }^{1,2 *}$ \\ ${ }^{1}$ International Research Center for Architectural Heritage Conservation, Shanghai Jiao Tong University Shanghai, China - \\ longyunren01@gmail.com \\ ${ }^{2}$ School of Design, Shanghai Jiao Tong University Shanghai, China - ykcao@sjtu.edu.cn
}

KEY WORDS: Viewshed analysis, ArcGIS, QGIS, Hisctoric Towns, Urban Heritage, Conservation Planning

\begin{abstract}
:
This paper discuss an application of the GIS software to analysis the visual effect from specific observation points in the historic towns. The viewshed tool in GIS platforms, including ArcGIS and QGIS, are applied in order to generate observation points and viewshed maps. Dozens of key nodes are selected in Xinchang Ancient Town, such as the protected buildings, the historic bridges, and the historic street intersections, as the observation points of viewshed analysis. The result of the analysis is to generate the viewshed map from each observation point. Subsequently, the observation points are merged and the result of the viewshed analysis of the whole ancient town is created. Based on the viewshed analysis results, the characteristics of the visual effect in the town with gentle terrain and dense building is discussed. The features of the ancient town remind elements that need attention in conservation planning, and guides the building regulation within and outside the set boarder of the protected area.
\end{abstract}

\section{INTRODUCTION}

\subsection{Research Question}

Historic towns located in the suburban areas of large cities are threatened with the loss of their unique landscape due to the high speed of urbanization. In the core area of the old town, historical buildings may be demolished and replaced by the new ones; in the buffer zone of the core area, high-rise buildings are being erected. Therefore, both the visual scenery within the core area of the historic towns and the skyline that can be seen from the historic towns change. For example, when standing on the stone bridge in the middle of the river in an old town, will people see the scenery as it was one hundred year ago, or will people see the high-rise residential buildings newly built in the development zone in the distance?

In this paper, we discuss an application of the viewshed analysis tool in the GIS platforms, which is a method to generate viewshed maps from selected vantage points. The viewshed maps are generated so as to summarize the visual features of the historic urban landscape and support the development of specified building guidelines for construction activities within the core area and the buffer zone.

\subsection{Research Background}

The viewshed analysis is one kind of visibility analysis applied in various landscapes. The visibility analysis is developed along with the evolution of $3 \mathrm{D}$ technologies for city modelling. As early as in 2010, researchers (J. Moser et al. 2010) listed the visibility analysis among the four major kinds of 3D GIS Analysis for virtual city models: proximity, overlay; spread/flow analysis; 3D density; and visibility analysis. The article cited a viewshed analysis of two observers to an airport apron and runway as the case study of visibility analysis (de Smith et al. 2010). The case study generated the map of radio propagation and supported the installation of positioning facilities.

In the past ten years, viewshed analysis has become a typical feature in common GIS software, such as ArcGIS (ESRI 2016), GRASS (Neteler et al. 2012) or ERDAS (ERDAS 2015) (Z. Cuckovic 2016). The advanced viewshed analysis plug-in is provided for the open source Quantum GIS software by Zoran Cuckovic, with standard binary viewshed and other features including the information on depth below horizon, mapping of visual horizon, and intervisibility networks.

It is still rare that the viewshed analysis is applied in the Chinese historic town. The GIS-based spatial analysis is usually applied in the research and teaching in archaeological sites in China (Zhang 2018), but not in the urban landscape. There are also case studies focusing on the visibility analysis and other quantitative approach to the height control of the outer space of historical cultural relics without employing GIS software (Xie et al. 2014).

\subsection{Relevance}

The Xinchang Ancient Town is a "Jiangnan Water Town" located about 38 kilometers away from downtown Shanghai. At present, the Xinchang Ancient Town retains a large number of material and intangible cultural heritage, and its conservation faces a great challenge (Ruan et al. 2014). Therefore, the comprehensive Conservation Planning of Xinchang Ancient Town becomes especially important. The revision of the Conservation Planning, including the delineation of the core area and the buffer zone of the ancient town, the identification of heritage elements, and the guidelines for building height regulations, should be carried out with a full analysis of the conditions in the old town. The case of Xinchang Ancient Town is typical among old towns, especially the Chinese water town

* Corresponding author 
in the Jiangnan area with gentle terrain and densely buildings, and the method of viewshed analysis can be applied in usual urban landscape as well.

\section{RESEARCH METHOD}

\subsection{The Basis of the Viewshed Analysis}

The viewshed analysis is based on the shading relationship between the viewer, the occluding object, and the target object (Figure 1). In the schematic diagram, $\mathrm{H}$ is the height of the target object relative to the viewer, $h$ is the height of the occluding object relative to the viewer, $\mathrm{L}$ is the distance from the target object to the viewer, and 1 is the distance from the occluding object to the viewer.

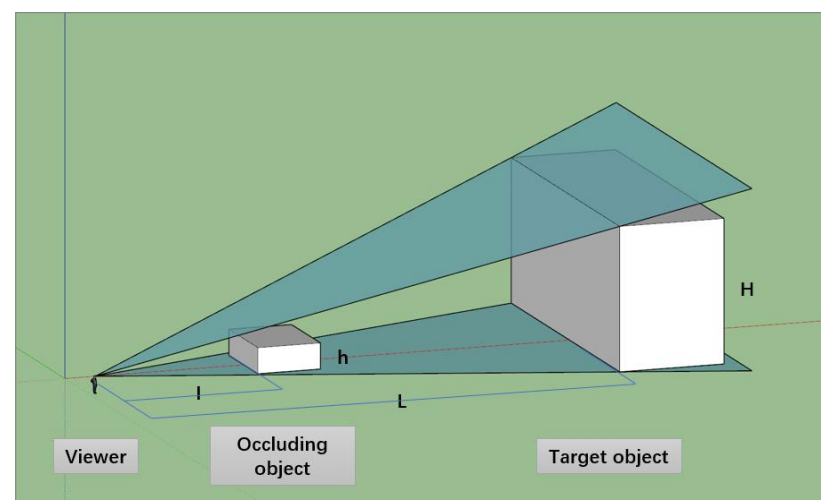

Figure 1. The shading relationship

(Drawn by the author based on Zhang, 2019)

When the positions of the viewer, the occluding object, and the target object are set, the value of 1 and $\mathrm{L}$ are determined. The formula to calculate the value of $\mathrm{h}$ is:

$$
h=\frac{H \times L}{l} .
$$

When $h<\frac{H \times L}{l}$, the target object can be seen by the viewer. When $h>\frac{H \times L}{l}$, the occluding object hide the target object from view, and the target object cannot be seen by the viewer.

As stated in 1.2 (Research Background), the common GIS software provides a view area analysis tool that uses topographic data to generate a map of the extent of visibility at a given observation point. The tool can determine the location of a raster surface that is visible to a set of observation point elements, which is useful when trying to determine an object is visible or not. For example, in the case provided by ERSI, the field of view of the observation tower is determined with the ArcGIS viewshed analysis tool (Figure 2, Esri, 2020). In the elevation raster data in the picture on the left, light shading stands for higher altitude. The height of land is shown, and the observation tower is marked as a green triangle. The height of the observation tower can be specified in the analysis. In the output viewshed on the right, the green pixels can be seen from the observation tower, and the red pixels are not visible.
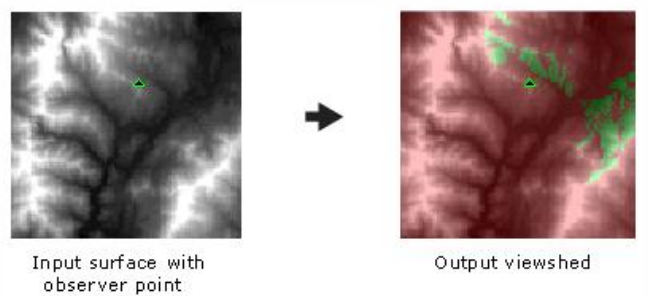

Figure 2. Application of the ArcGIS viewshed analysis tool, with the visible range in green. (Esri, 2020)

\subsection{Software and Tools}

Both commercial GIS software and open-source GIS software provide the feature of viewshed analysis. In the ArcGIS software, view area analysis tool use topographic base data to generate a map of the extent of visibility at a given viewpoint. The main tools for view analysis are viewshed, viewshed2, and visibility, all located in ArcToolbox - 3D AnalystTools Visibility. To set the height of the viewpoint, for example, to simulate the viewpoint of a person standing at the highest point of a bridge, the "Viewshed2" tool is selected, which allows entering the height parameters of the viewpoint.

The open-source Quantum GIS (QGIS) software also provides the "visibility analysis" plugin. In the plugin, the workflow is divided into to two steps. First, a set of observer points is created with the "Create observer points" tool, and then the visibility is calculated with the "viewshed" tool. In the first step, the input data are processed and written with standardized field names, including "Observer height", "Target height", and "Radius of analysis". In the second step, the "viewshed" tool is able to produce "binary viewshed", "depth below horizon", and "horizon".

\subsection{General Steps}

With the viewshed analysis tools, the viewshed analysis is carried out in the Xinchang Ancient Town. The building roofs of the ancient town are seen as a part of the input terrain and thus identify the buildings visible and invisible at each viewpoint. The general steps of the viewshed analysis are shown as followed (Figure 3):

1. Make a terrain model combined with topographic data and building height;

2. Create observation points;

3. Generate viewshed maps.

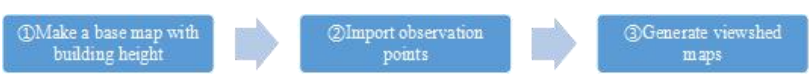

Figure 3. General steps of the viewshed analysis

\section{THE CASE STUDY OF XINCHANG}

\subsection{Generating the Terrain Model in Raster Format}

Since the terrain model in a raster grid format must be provided when running the viewshed analysis tool, generating a base map with the building height in raster format is a crucial part of this research. The existing basic data of this research provided by the client includes the topography CAD, the building outline in $\mathrm{CAD}$ with floor numbers, the building outline of the core area in shapefile (including height information), the building surface in shapefile (without height information), and new buildings planned and constructed in the buffer area (with Planning 
documents for reference). Therefore, the number of floors of the buildings and the building outlines are used to combine with the terrain data to generate the base map in raster format for viewshed analysis. This step can be realized with both ArcGIS and QGIS. In ArcGIS, for example, the steps taken are as follows:

1. Using the planning documents as a basis, draw the new buildings planned and constructed in the buffer zone on CAD, and delete the buildings in the core area;

2. Import CAD into GIS, and add height data for the buildings in the buffer zone through Spatial Join;

3. Clear building height data in the buffer zone, delete unreasonable building outlines, and modify unreasonable building heights;

4. Convert the building surface of the buffer to the raster format according to the height value, and set the value of the blank ground to 0 ;

5. Convert the building surface of the core area to the Raster format according to the height value, and set the value of the blank ground to 0 ;

6. Use the Plus function to merge the buffer raster and the core area raster to complete the building height base map;

7. Input the elevation points from $\mathrm{CAD}$, and use the "interpolate" tool to generate the topographic map;

8. Combine the building height base map with the topographic map using raster calculator.

The output is a terrain model with building height in the raster format (Table 1). The elevation of Xinchang is low, with a maximum value of 11.48 meters and a minimum value of 2.62 meters. Most of the elevation points in the core area have a value between 4.3 meters and 5.1 meters, with a height difference of no more than 1 meter. From the terrain model generated on the left, we can see that the terrain of Xinchang is very gentle. From the terrain model on the right, we can see that the high-rise buildings outside the significantly changed the topography of the Xinchang Ancient Town.

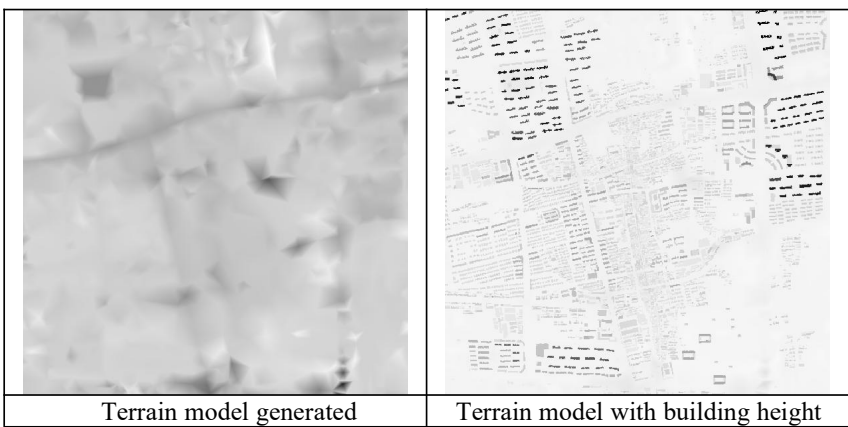

Table 1. The terrain model of Xinchang Ancient Town

\subsection{Generating Observation Points and Viewshed Maps}

The procedure of generating observation points in different GIS software are only slightly different. In the ArcGIS software, importing bridge observation points by adding a viewpoint height field in the bridge layer, selecting the location point of the bridge as the observation point, and exporting. In the QGIS software, the "Create observer points" tool is used (see Chapter 2.2).

The viewpoints selected for analysis in this study includes historical bridges, historical buildings, and Landscape corridors and nodes.

\subsubsection{Historical bridges as the observer points}

Ten ancient bridges in Xinchang ancient town were selected as the visual field analysis points (Table 2). The highest point of the bridge plus the human eye height $(1.6 \mathrm{~m})$ is used for the view field analysis, and the analysis range was 360 degrees. Most of the bridges are the lowest level of recognized Cultural Relics (Pudong New Area Cultural Relics Protection Site), and the Qianqiu Bridge is the recognized Cultural Relics on the district level (Pudong New Area Cultural Relics Protection Unit).

\begin{tabular}{|c|c|c|}
\hline No. & Bridge & Protection Level \\
\hline 1 & Hongfu Bridge & $\begin{array}{l}\text { Pudong New Area Cultural } \\
\text { Relics Protection Site }\end{array}$ \\
\hline 2 & Dongcang Bridge & $\begin{array}{l}\text { Pudong New Area Cultural } \\
\text { Relics Protection Site }\end{array}$ \\
\hline 3 & Xicang Bridge & $\begin{array}{l}\text { Pudong New Area Cultural } \\
\text { Relics Protection Site }\end{array}$ \\
\hline 4 & Qinglong Bridge & $\begin{array}{l}\text { Pudong New Area Cultural } \\
\text { Relics Protection Site }\end{array}$ \\
\hline 5 & Qianqiu Bridge & $\begin{array}{l}\text { Pudong New Area Cultural } \\
\text { Relics Protection Unit }\end{array}$ \\
\hline 6 & Fuan Bridge & $\begin{array}{l}\text { Pudong New Area Cultural } \\
\text { Relics Protection Site }\end{array}$ \\
\hline 7 & Shouen(Baojia) Bridge & $\begin{array}{l}\text { Pudong New Area Cultural } \\
\text { Relics Protection Site }\end{array}$ \\
\hline 8 & Yujianong Bridge & - \\
\hline 9 & Taiping Bridge & - \\
\hline 10 & Nanli Bridge & - \\
\hline
\end{tabular}

Table 2. The old bridges selected as the viewpoints for the viewshed tool. (Part of the complete data, proposed by Chinese Academy of Cultural Heritage)

The physical appearance of the bridge and the view from the bridge are shown in Figure 4 and Figure. The viewshed generated with QGIS "visibility analysis" plug-in from Hongfu Bridge is shown in Figure 5. The height of the observation point is set at 3.97 meters (the highest point of the bridge floor is 1.37meters above the ground, plus 1.6 meters for the height of the human eye). The 3-Dimensional relationship between the viewpoint of and the surrounding buildings is shown in Figure 6 (generated with the QGIS plug-in "Qgis2threejs").

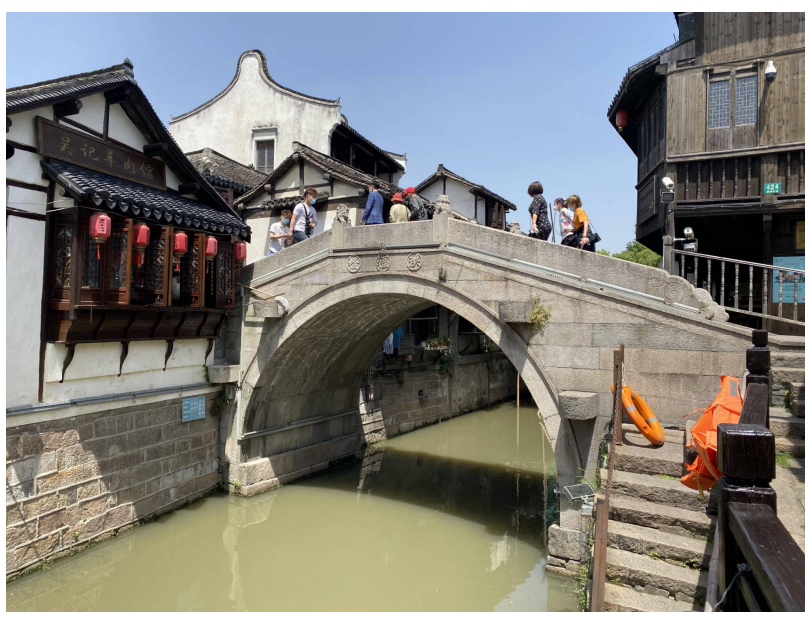

Figure 4. Hongfu Bridge (Photo by Bowen Qiu) 


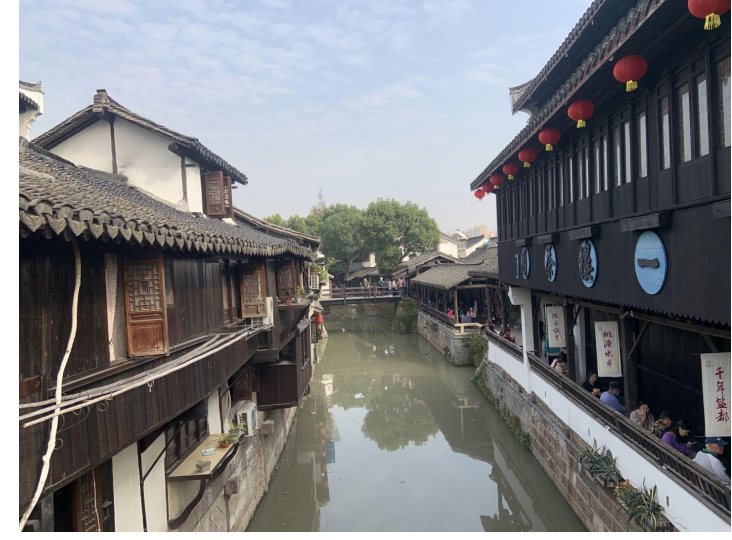

Figure 5. On Hongfu Bridge looking East (Photo by the author)

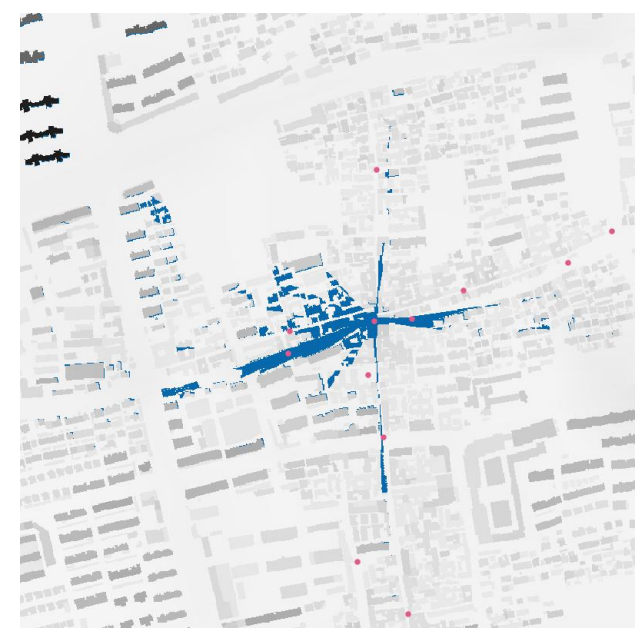

Figure 6. The Viewshed from Hongfu Bridge in blue

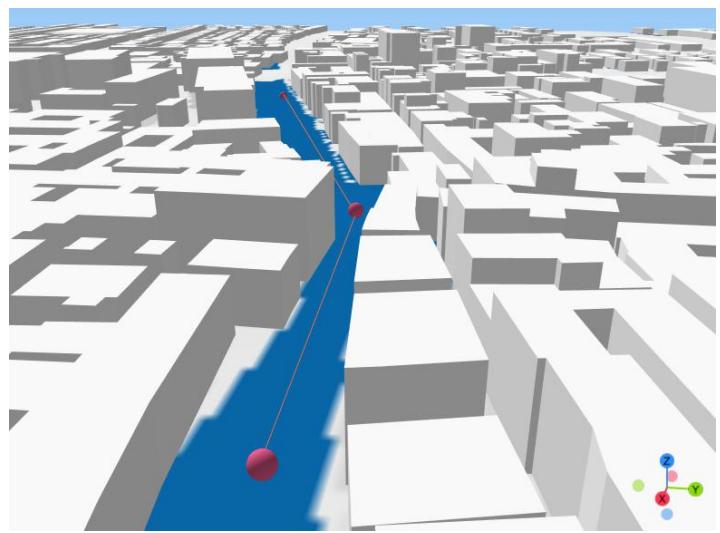

Figure 7. The Viewshed of Hongfu Bridge (pink ball in the middle), looking from East to West

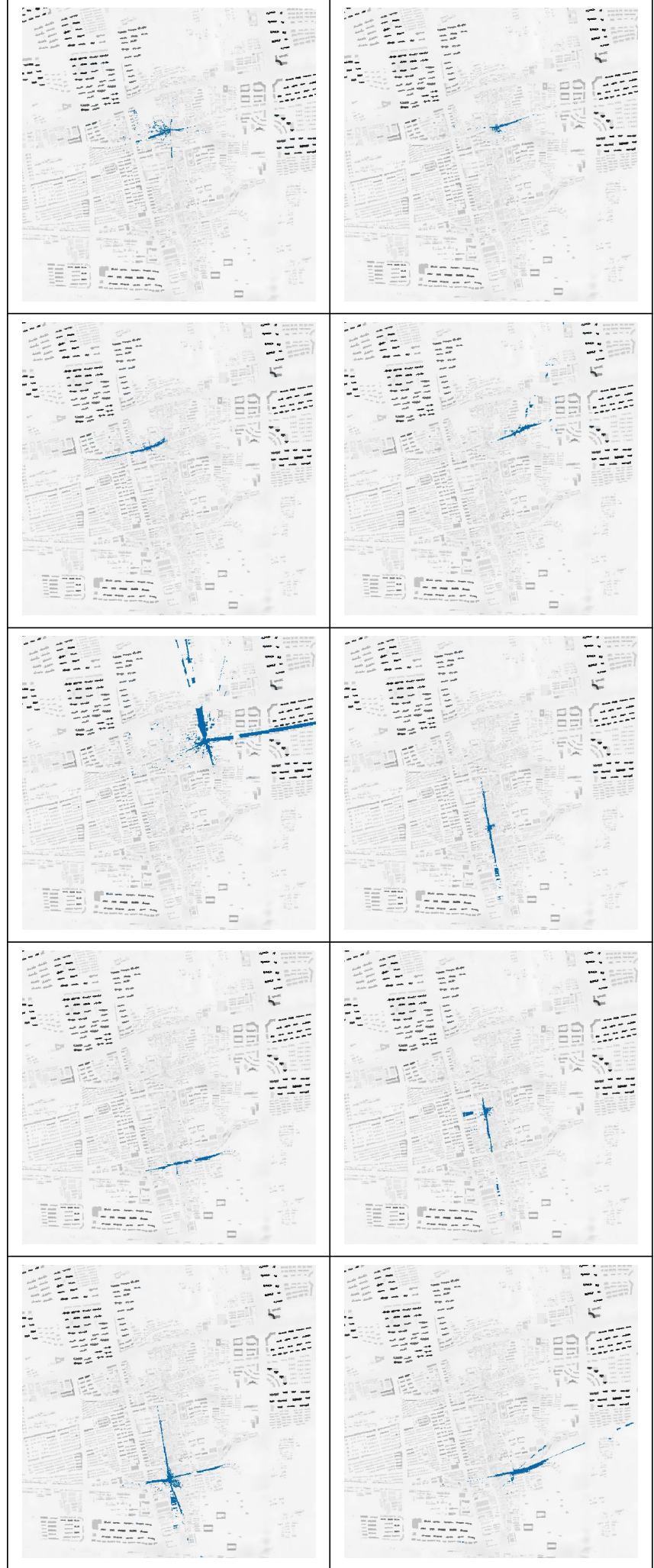

Table 3. The viewshed maps from historical bridges 
3.2.2 Historical buildings as observation points: Five ancient buildings in the ancient town of Xinchang were selected for analysis of the viewshed analysis (Table 4). The observation points are added at the locations of window openings at the edges of buildings. For buildings with two floors, the observation height is the height of the first floor plus the height of the human eye (1.6 meters). The viewing angle is determined by the direction of windows. For buildings with windows on three sides, for example the Diyilou Bookstore (Figure 7), three observation points are added (Figure 8). The green part stands for area that can be seen from one window, and the blue part stands for area that can be seen from two windows.

\begin{tabular}{|l|l|l|}
\hline No. & \multicolumn{1}{|c|}{ Building } & \multicolumn{1}{c|}{ Protection Level } \\
\hline 1 & Diyilou Bookstore & Shanghai Cultural Relics Protection Unit \\
2 & Xinlong Pawnshop & Shanghai Cultural Relics Protection Unit \\
3 & Xinchang Zhang's & Pudong New Area Cultural Relics \\
& House & Protection Site \\
4 & Xinchang & Excellent Historical Building \\
& Zhonghualou & Pudong New Area Cultural Relics \\
5 & Nanshan Temple & Protection Unit \\
\hline
\end{tabular}

Table 4. The historical buildings selected as the viewpoints for the viewshed tool. (Part of the complete data, proposed by Chinese Academy of Cultural Heritage)

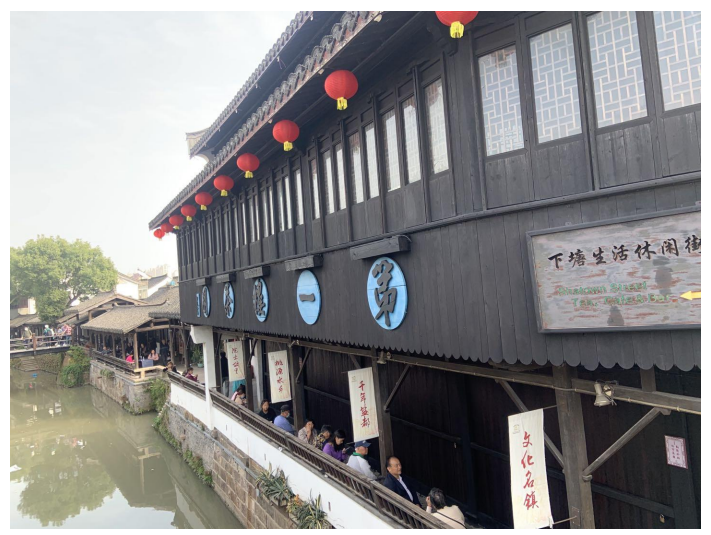

Figure 8. The North Elevation of the Diyilou Bookstore (Photo by the author)

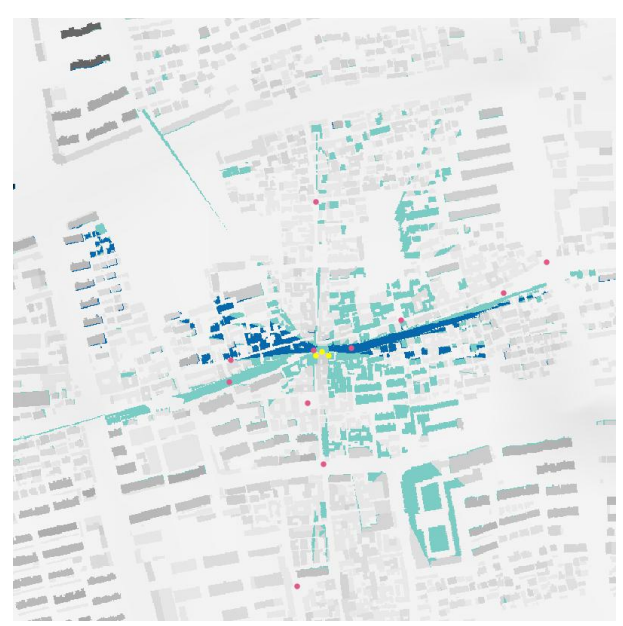

Figure 9. The $270^{\circ}$ viewshed from Diyilou Bookstore (yellow points).

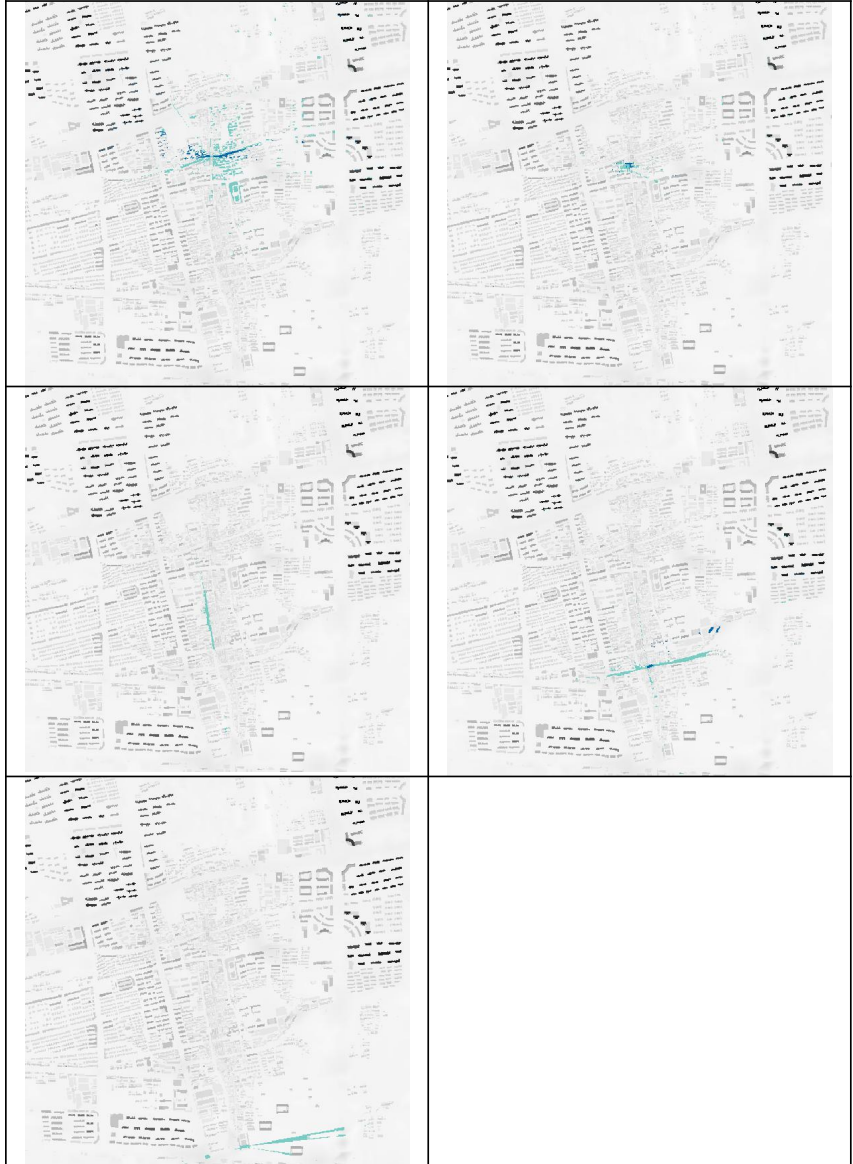

Table 3. The viewshed maps from historic buildings

3.2.3 Landscape corridors and nodes as observation points: The important landscape corridors such as Xinchang Street and Houshi River, and the important landscape nodes such as Stalagmite Pailou are selected for visual field analysis. The way to import landscape corridors, nodes observation points: add observation points in the selected designated location.

\begin{tabular}{|c|c|c|}
\hline No. & $\begin{array}{l}\text { Landscape } \\
\text { corridors and } \\
\text { nodes }\end{array}$ & Location \\
\hline 1 & Stalagmite Pailou & - \\
\hline 2 & Sanshierpin Pailou & - \\
\hline 3 & Xinchang Street a & $\begin{array}{l}\text { Intersection of Xinchang Street and } \\
\text { Wangjia Alley (historic alley) }\end{array}$ \\
\hline 4 & Xinchang Street c & $\begin{array}{l}\text { Intersection of Xinchang Street and } \\
\text { Songiia Alley (historic alley) }\end{array}$ \\
\hline 5 & Xinchang Street $d$ & $\begin{array}{l}\text { The intersection of Xinchang Street } \\
\text { and Yangshe East and West Alley } \\
\text { (historical alley) }\end{array}$ \\
\hline 6 & Hongdong Street & $\begin{array}{l}\text { The intersection of Hongdong Street } \\
\text { and Chaguan Alley (historical alley) }\end{array}$ \\
\hline 7 & Hongxi Street & $\begin{array}{l}\text { The Intersection of Hongxi Street and } \\
\text { Zhangye Alley (historical alley) }\end{array}$ \\
\hline 8 & $\begin{array}{l}\text { The Intersection of } \\
\text { South Wuzao Port } \\
\text { and Houshi River }\end{array}$ & - \\
\hline
\end{tabular}

Table 4. Landscape corridors and nodes selected as the viewpoints for the viewshed tool. (Part of the complete data, proposed by Chinese Academy of Cultural Heritage) 


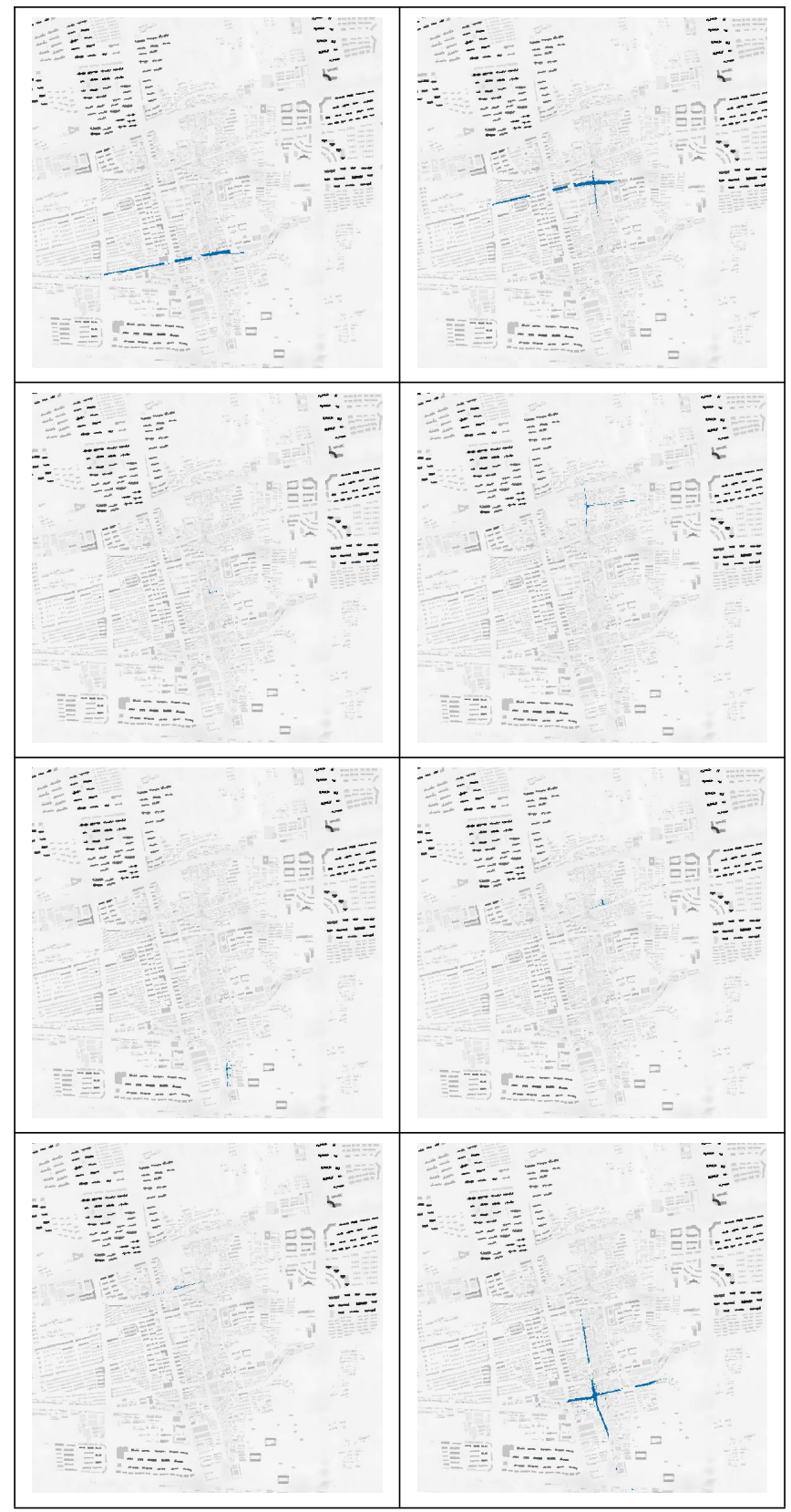

Table 5. The viewshed maps from landscape corridors and nodes

\subsection{Results}

\subsubsection{The Comprehensive Viewshed Map}

The observation points are combined together to produce the viewshed analysis results of the whole town (Figure 10). Zooming in shows that a new project which is planned near the ancient town with a height limit of 59 meters, has a great impact on the visual effect from the town (Figure 11).

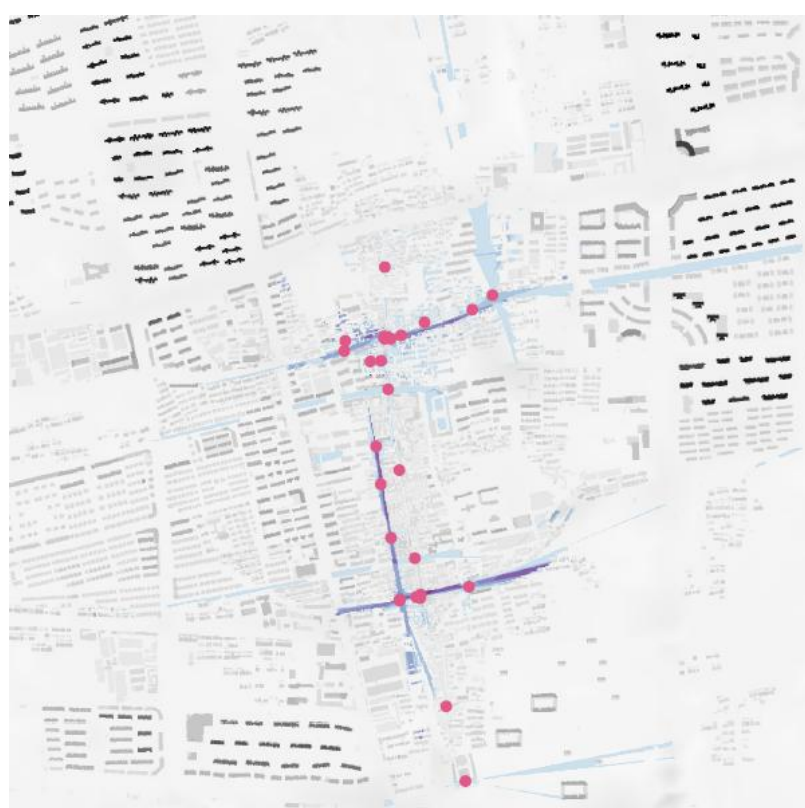

Figure 10. The combined viewshed map in Xinchang Ancient Town. Generated with QGIS with the visibility analysis plugin. Darker purple color stands for more chances to be seen.

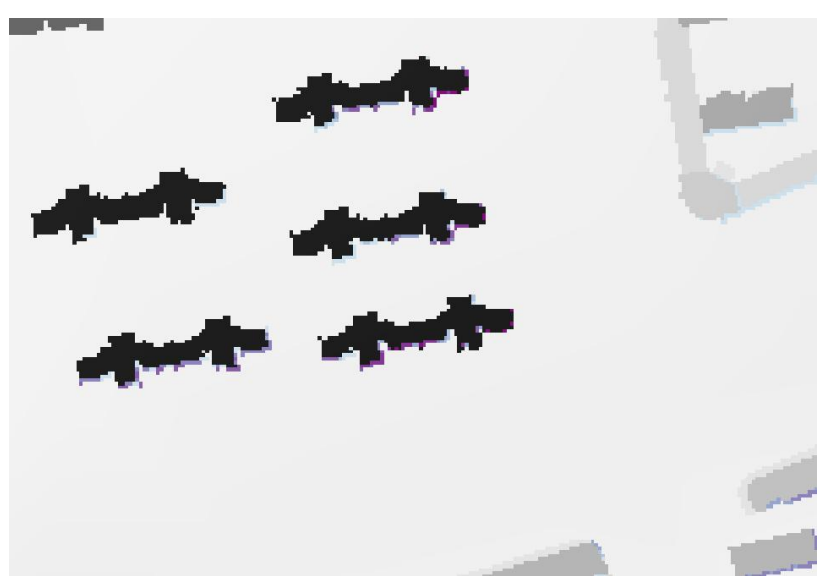

Figure 11. The high-rise buildings near the core area of the old town have purple and blue lines on the edge, meaning it has a great impact on the town's visual effect.

\subsubsection{Characteristics of the Visual Effect in the} Xinchang Ancient Town

Summarizing the features of the viewshed from each observation point, we can see that the visibility in the key nodes in the Xinchang Ancient Town is quite unique. First, the viewing angle is relatively narrow along Xinchang Street and other landscape corridors. This result is in line with people's impression of the narrow and deep alleys in the ancient town. On the other hand, the viewing angle on historic bridges and on the second floor of historic buildings are usually wider due to the higher viewer height. People can have a wide, open view and will be able to look down on the roofs and the rivers at these points.

\subsubsection{Heritage Elements in the Conservation Planning}

The result of viewshed analysis suggests that different kinds of heritage elements in the core area of the Xinchang Ancient need to be considered in the Conservation Planning. The landscape corridors, including the historic street and the historic river, need special protection. The color, height, and style of the facade of the buildings alongside these corridors, should stay 
consistent in order to avoid causing too much change to the visual effect. The distinctive double-sloped roof should also be protected because they are crucial when looking from a high viewpoint.

\subsubsection{Building Guidelines}

The new high-rise buildings near the core area of the Xinchang Ancient Town will strongly affect the skyline. Therefore, the construction should be carefully controlled in the buffer zone outside the core area. Within the core area, historic buildings should be repaired with original material and craft when needed.

\subsection{Conclusion}

The viewshed analysis can be a useful tool when investigating the visual features of the urban landscape. It could be applied in many situations, especially when the area that need to be surveyed is large, and the historical status on the site is complicated. The case study of the Xinchang Ancient Town proved that the viewshed analysis can show the visual characteristics of an old town in a direct way. It could support the identification of heritage elements and provide necessary information for the Conservation Planning.

The method of viewshed analysis has its advantages and limitations. The leading advantage is that it is easy to learn and use. The viewshed tool is accessible through different kinds of GIS software, and it can provide informative pictures with simple operation. The user do not have to be knowledgeable about 3D modelling to perform the viewshed analysis, and the results - the 2D diagrams - can be disseminated and interpreted by large audience. Besides, the method of the viewshed analysis only requires the minimum input data. It can work with a CAD file that can usually obtained from the client. When the terrain is flat, the influence of topographic data of the analysis result could be ignored, and the viewshed is basically determined by the building height. In that case, the viewshed analysis only needs to have the vector data of buildings and their height.

However, the method also has many limitations. The first is that its precision is limited due to the hardware restrictions. The processing time of the viewshed analysis depends on the resolution. In the case study, the raster accuracy of the terrain model is $1 \mathrm{~m}^{*} 1 \mathrm{~m}$ (cell size $=1$ ), and the processing time is about one minute or less. The cell size is accepted because when the raster precision is $0.1 \mathrm{~m} * 0.1 \mathrm{~m}$ (cell size $=0.1$ ), the size of the terrain model reaches $2.7 \mathrm{G}$, and the processing time for generating a result map is more than ten minutes, and is likely cause the GPU of the graphics card to crash. Therefore, the accuracy of the output is very limited. The second disadvantage of the method is that it is seeing all the roofs of the buildings as flat roofs. This might cause some deviations in the results because most of the historical buildings in the core area of the old town have double-pitched roof whose occlusion effect is slightly different from the flat roof. The third disadvantage is that the result of the viewshed analysis is expressed on a $2 \mathrm{D}$ map, so a buildings whose facade is seen but not the roof is represented as a thin line in the result map, and it might be difficult to identify it.

\section{ACKNOWLEDGEMENTS}

Part of the research is carried out within the preliminary work of the revision of the Conservation Plan of Xinchang Ancient Town, commissioned by Jiayu Fan of the Chinese Academy of Cultural Heritage and contacted by $\mathrm{Dr}$. Yue $\mathrm{Lu}$ of the International Research Center for Architectural and Cultural Heritage Conservation of Shanghai Jiaotong University.
Chengzhuang Chen, the engineer of the Chinese Academy of Cultural Heritage, offered counseling, and Di Zhu, Bowen Qiu and Mengjie Yuan of the Research Center provided help in base map processing, analysis operation, and graph making, etc. We would like to thank them.

\section{REFERENCES}

De Smith, M., Goodchild, M.F., Longley, P.A., 2009. Geospatial Analysis. A Comprehensive Guide to Principles, Techniques and Software Tools. 3rd edition. Viewsheds and RF propagation.

http://www.spatialanalysisonline.com/output/html/Viewshedsan dRFpropagation.html

Moser, J., Albrecht, F. and Kosar, B., 2010. Beyond visualisation - 3D GIS analyses for virtual city models. International Archives of the Photogrammetry, Remote Sensing and Spatial Information Sciences, 38(4), p.W15.

Neteler, Markus, M. Hamish Bowman, Martin Landa, and Markus Metz. 2012. "GRASS Gis: A Multi-Purpose Open Source Gis.” Environmental Modelling \& Software 31: 124-30. doi:http://dx.doi.org/10.1016/j.envsoft.2011.11.014.

Ruan, Y., Yuan, F., Ge, L., 2014. Xinchang Ancient Town. China Publishing Group Corp, Beijing. (In Chinese: 阮仪三等. 新场古镇[M]. 中国出版集团:北京, 2014)

Xie, H., Zhou, Q., 2014. Preliminary Study on the Height Control of the Peripheral Space of the Historical Relics and Historic Sites Conservation Area. Urban Planning, 3, 60. (In Chinese: 谢晖,周庆华.历史文物古迹保护区外围空间高度控 制初探[J].城市规划,2014(3):60.)

ERDAS. 2015. "ERDAS Imagine Suite 2015." Norcross: Hexagon Geospatial.

Schulz, S., Dong, N. and Zhang, S., 2015. GIS-Based Digital Applications on Maintenance and Preservation for Traditional Chinese Gardens. International Archives of the Photogrammetry, Remote Sensing \& Spatial Information Sciences, 40.

Cuckovic, Z., 2016. Advanced viewshed analysis: a Quantum GIS plug-in for the analysis of visual landscapes. Journal of Open Source Software, 1(4), p.32.

ESRI. 2016. “ArcGis Desktop: Release 10.4." Redlands: Environmental Systems Research Institute.

Liu, R., 2018. GIS-based landscape viewshed analysis of urban historical district: Taking Hengshan Road - Fuxing Road historical and cultural style area as an example. Urban Construction Theoretical Research (Electronic Edition) 07, 25. (In Chinese: 刘再. 基于 GIS 的城市历史街区景观视域分析一 一以衡山路-复兴路历史文化风貌区为例 [J].城市建设理论研 究(电子版),2018(07):25.)

Zhang, H., 2018. GIS and Archeology Spatial Analysis Practice Course. Peking University Press, Beijing. (In Chinese: 张 海.GIS 与考古学空间分析实践教程[M]. 北京大学出版社: 北 京,2018) 
The International Archives of the Photogrammetry, Remote Sensing and Spatial Information Sciences, Volume XLVI-M-1-2021

28th CIPA Symposium “Great Learning \& Digital Emotion”, 28 August-1 September 2021, Beijing, China

Zhang, L., 2019. Exploration of Urban Construction Height Control Based on Computer Vision Analysis. Exploration of Urban Construction Height Control Based on Computer Vision Analysis 06,83-85. (In Chinese: 张利敏.基于计算机视 觉分析的城市建设高度控制探索 [J].中外建筑,2019(06):8385.)

"Using Viewshed and Observer Points for visibility analysis", ArcGIS for Desktop,

https://desktop.arcgis.com/en/arcmap/10.3/tools/spatial-analysttoolbox/using-viewshed-and-observer-points-for-visibility.htm (Retrieved: 2021-07-07) 